\title{
The Influence of Determined Tax Load, Tax Planning, and Profitability in Profit Management in The Company Manufacturing The Mining Sector, The Coal Sub Sector Listed on The Indonesia Stock Exchange Year
}

\author{
Imam Hidayat ${ }^{1}$, Pinka Oktaviani Sutria ${ }^{2}$ \\ 1,2Universitas Muhammadiyah Tangerang \\ 1,2Jalan Perintis Kemerdekaan I Babakan No.33, Cikokol, Kec. Tangerang, Kota Tangerang, \\ Banten 15118 \\ e-mail: imam accounting@yahoo.com ${ }^{1}$, sutriapinka@gmail.com ${ }^{2}$
}

To cite this document :

Hidayat, I., \& Sutria, P.O. (2023). The Influence of Determined Tax Load, Tax Planning, and Profitability in Profit Management in The Company Manufacturing The Mining Sector, The Coal Sub Sector Listed on The Indonesia Stock Exchange Year. APTISI Transactions on Management (ATM), 7(1), 79-85.

DOI :

https://doi.org/10.33050/atm.v7i1.1833

\section{Abstract}

This study aims to analyze the effect of deferred tax expense, planning, and profitability on earnings management. The method used in sampling is using a purposive sampling method. The population in this study is manufacturing companies in the mining sector listed on the Indonesia Stock Exchange (IDX) in 2018-2020. Based on the established criteria, 11 companies have been obtained. This study indicates that the deferred tax expense variable does not affect earnings management; tax planning affects earnings management because profitability affects earnings management. The variables of deferred tax expense, tax planning, and profitability affect earnings management. Profitability has a significant effect on earnings management of manufacturing companies in the Coal Mining sector on the Indonesia Stock Exchange in the 20182020 period. Deferred Tax Expenses, Tax Planning, and Profitability simultaneously affect the profit management of manufacturing companies in the Coal sub-sector Mining sector on the Indonesia Stock Exchange in the 2018-2020 period. Deferred Tax Expenses have no significant effect on earnings management in manufacturing companies in the Coal Mining sector on the Indonesia Stock Exchange in 2018-2020. Tax planning significantly affects earnings management for manufacturing companies in the Coal Mining sector on the Indonesia Stock Exchange in the 2018 period 2020.

Keywords: Deferred Tax Expense, Tax Planning, Profitability, Earnings Management.

\section{Introduction}

The preparation of financial statements by management aims to convey information about the company's financial and economic conditions for a certain period. Information is the output of processed data that has benefits and a dominant role in a company. Internal parties and external parties need financial information as users of the company's financial statements. Suwardjono states that internal parties, namely management, need financial statement information for planning, coordinating, and controlling company operations. At the same time, external parties consist of investors, creditors, customers: suppliers, government agencies, educational institutions, and the general public. As company managers, managers must access better and quality information about the company's performance. One measure of company performance that is often used in business decision-making is the profit generated by the company. The company is still considered essential information for investors, creditors, and company owners. 
Investors, creditors, and company owners can estimate the strength of earnings to measure risk in investment and credit.

On the other hand, the company's profit is an engineering target for the management to maximize its satisfaction. Therefore, the management as the executor and person in charge of the company's operations can increase and decrease its profits according to their wishes. (earnings management).

Earnings management is an effort to increase and decrease profits in compiling and presenting financial reports to benefit themselves. Some motivations for earnings management are the bonus plan hypothesis, debt to equity hypothesis, and the political cost hypothesis. The bonus plan hypothesis states that managers in companies with bonus plans tend to use accounting methods to increase current income. The debt to equity hypothesis states that in companies that have an enormous debt to equity ratio, the company's managers tend to use accounting methods that will increase revenue or profits. The political cost hypothesis states that large companies whose operations touch most of the public will tend to reduce reported profits.

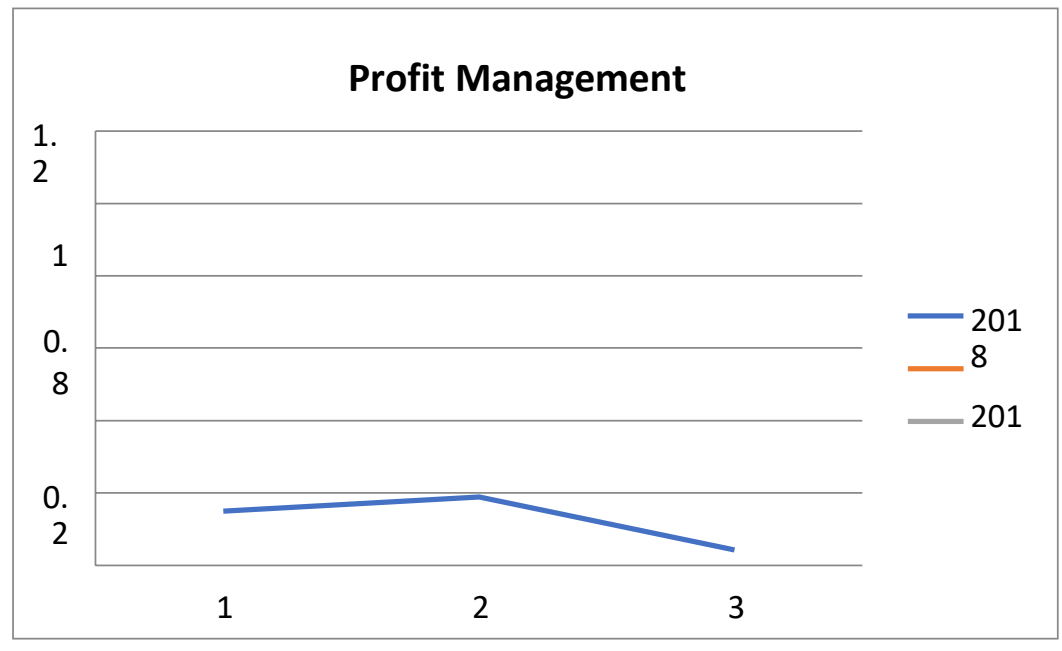

Gaph 1. Profit Management

The statistical results above show the fluctuation of 11 coal mining sub-sector manufacturing companies in 2018-2020, where the highest average value occurred in 2019 with a residual value of 0.189512 and the lowest average value occurred in 2020 with a residual value of 0.043033 .

Deferred Tax occurs due to the difference between income tax payable (income tax calculated based on the actual taxable income paid to the government) and income tax expense (income tax calculated based on income before Tax) as long as temporary differences are involved. If the profit generated is significant, the tax burden will also be large to reduce the profits that will be obtained by the company.[1] The results of previous research conducted by According to Lutfi M Baradja Yuswar Zainul Basri Vertari Sasmi Deferred tax expense has a positive effect on Earnings Management. In contrast, according to Randi Febrian Tertiarto, Wahyudi Ahmad Subek, Deferred tax expense does not positively affect Earnings Management.

Tax planning is the first step in tax management. In general, the emphasis on tax planning is to minimize tax liability. The purpose of tax planning is to engineer so that the tax burden can be reduced as low as possible by utilizing existing regulations, but it is different from the purpose of the legislators, then tax planning here is the same as tax avoidance because, in essence, both of them are trying to maximize after-tax income because of taxes. It is an element of reduced profit available, both for distribution to shareholders and reinvestment. Minimizing tax obligations can be done in various ways, both for those who still fulfill tax obligations and those who violate tax provisions. The results of previous studies Lutfi M Baradja Yuswar.

Zainul Basri Vertari Sasmi and Randi Febrian Tertiarto Wahyudi Ahmad Subek's tax planning positively affect earnings management, while Budi Setyawan Harnovinsah, it does not affect earnings management.[2] 
Companies with high profitability will generate high profits, so it is related to the amount of compensation or bonuses received by management. llya [3] said that when profit is used as a benchmark in the provision of compensation or bonuses, it can create a stimulus to managers in managing financial statement data so that the compensation or bonuses that are expected to be received by management. So companies that have high profitability will be more likely to practice earnings management. The results of previous studies Budi Setyawan Harnovinsah, profitability significantly influences earnings management.

\section{Positive Accounting Theory}

Positive accounting theory is a theory that tries to make good predictions of events in the real world. Positive accounting theory is concerned with predicting actions, such as selecting accounting policies by managers (agents) in a company and how managers respond to the proposed new accounting standards.[4] Based on positive accounting theory, this will lead to a positive flow from several experts.

Positive accounting theory explains the observed accounting phenomena based on the reasons that cause an event to occur. So positive accounting theory aims to explain and predict the consequences of managers making confident accounting policy choices. The basis for these explanations and predictions is the contract process or agency relationship between managers and other groups, such as investors, creditors, auditors, capital market managers, and government institutions.[5]

Positive accounting theory is based on the premise that individuals always act based on personal motivation and maximize personal gain. In addition, positive accounting theory can also be associated with the phenomenon of managers' opportunistic behavior, where Watt and Zimmerman[6] explain three hypotheses behind managers' opportunistic behavior, namely: (1) Bonus Plan Hypothesis, where managers will choose accounting methods that can maximize bonuses. High, which can increase reported earnings, (2) Debt Covenant Hypothesis, namely the higher the company's debt ratio, the more likely it is for managers to choose accounting methods that can increase profits because they are closer to the covenants or credit regulations. This increases the possibility of credit irregularities and expenses. By choosing an accounting method that can increase profits, relax credit limits, and reduce the cost of technical errors, (3) Political Cost Hypothesis, where the more significant the company, the more likely, it is to choose an accounting method that can reduce profits, because if the company's profit is significant, the greater the tax to be paid and the higher the company is required to be responsible for the environment, the higher the cost automatically.

\section{Teori Agensi}

Agency theory explains the relationship or contract between the principal (owner) and the agent (manager or directors). Agency theory is defined as where one or more people (principals) engage or involve other people (agents) to perform some services for their benefit, which includes the delegation of some decision-making authority.[7] Theory the agency deals with two fundamental problems that can occur in agency relationships, namely: (1) occurs when the desires or goals of the principal and agent conflict, and it is challenging and expensive for the principal to be able to verify what the agent is doing, (2) problems with risk-sharing that arises when the principal and agent have different attitudes and risks.[8]

Risk in agency theory assumes that humans prefer increasing wealth over decreasing or decreasing wealth. This can be seen where the principal will try to maintain his capital by investing in many containers (diversifying his capital) to share the risk or avoid the existing risks. For agents themselves who potentially can manage company resources and there is a possibility of a decline in the value of the company's wealth and capital, the agent will also avoid risk.

Agency theory also assumes the existence of information asymmetry, which is where the agent who manages the company has more internal company information than the principal. This happens because the principal cannot continuously observe every action taken by the agent. Therefore, agents need to provide information, for example, financial reports to the principal on a regular and transparent basis. However, sometimes not all information is conveyed by agents to the principal, or even the conditions reported are different from the actual conditions on the ground. So the agent knows more information about the company than the other party (principal). The conflict of interest between the principal and the agent occurs because the agent does not always act in the principal's interests, so this triggers agency costs.

The Influence of Determined Tax Load, Tax Planning, and Profitability in Profit Management in The Company Manufacturing The Mining Sector, The Coal Sub Sector Listed on The Indonesia 


\subsection{Theoretical Framework}

Based on the explanation of the theoretical framework, it can be simplified into a framework of thought. The theoretical framework in this research can be described in Figure 1.

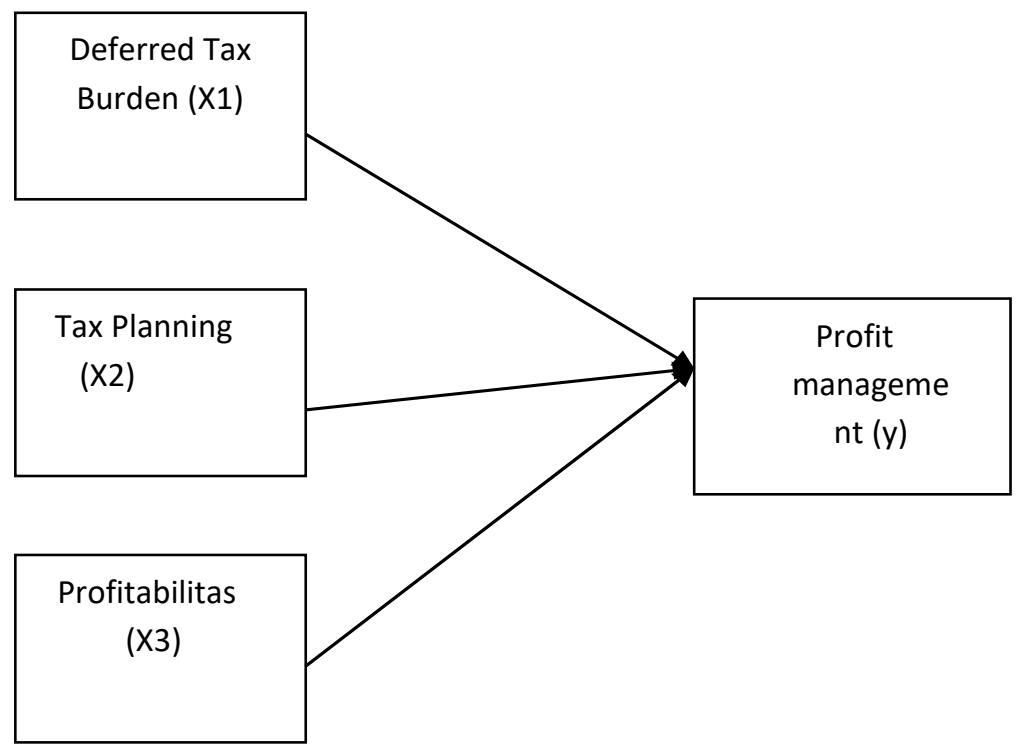

Figure 1. Theoretical Framework Model

\subsection{Hypotheses}

Research Hypothesis This study examines the causal relationship between the variables of deferred tax expense, tax planning, and profitability on earnings management.

The following is the development of the hypothesis of the variables studied:

\section{1.) Effect of deferred tax expense on earnings management}

Deferred tax can be understood as a result of temporary differences that can be deducted from the company's remaining losses (PSAK 46). Companies tend to reduce reported earnings in the context of tax deferral about earnings management. Philips, Pincus \& Rego [9] analyzed the use of deferred tax expense in identifying earnings management carried out to achieve three profit reporting objectives: avoiding losses, avoiding earnings declines, and avoiding failure to meet earnings predictions by analysts.[10] Deferred tax expense can be used to detect earnings management. This description is by Lutfi M Baradja Yuswar Zainul Basri Vertari Sasmi Deferred Tax Expense has a positive effect on Earnings Management.[11]

$\mathrm{H} 1$ : Deferred tax expense has a positive effect on earnings management.

\section{2.) The Effect of Tax Planning on Earnings Management}

Tax planning can be understood as minimizing tax payments as long as it is still within the applicable tax rules.[12] Companies that can do good tax planning impact decreasing profits through their tax obligations. This description is by Lutfi M Baradja Yuswar Zainul Basri Vertari Sasmi and Randi Febrian Tertiarto Wahyudi Ahmad Subek that tax planning has a positive effect on earnings management.[13]

H2: Tax planning has a positive effect on earnings management.

\section{3.) The Effect of Profitability on Earnings Management}

Profitability is a measure in detecting profit (profit) and is used as a criterion for evaluating the results of company activities. Profitability is one of the factors or motives for managers' opportunistic behavior towards earnings management practices, namely the political cost hypothesis.[14] Research by llya and Igan states that companies with high profitability tend to practice earnings management because they expect compensation or bonuses for the management. However, profits are used as a medium in terms of tax obligations for companies that report losses. In measuring the level of profitability with the calculation of Return on Assets 
(ROA), companies with high profitability and large scale are expected by regulators to fulfill obligations under applicable regulations, such as tax obligations, social responsibility, and others. [15] Budi Setyawan Harnovinsah, profitability significantly influences earnings management. H3: profitability has a significant effect on earnings management

\section{Result and Discussion}

The object of this research is a manufacturing company listed on the Indonesia Stock Exchange from 2018 to 2020 . The sample in this study amounted to 11 manufacturing companies in the coal mining sub-sector listed on the Indonesia Stock Exchange from 2018 to 2020 that meet the predetermined criteria. By using purposive sampling.

\begin{tabular}{|c|c|c|}
\hline $\begin{array}{l}\mathrm{N} \\
\mathrm{O} \\
\end{array}$ & $\begin{array}{l}\text { Kriteria } \\
\text { Sample } \\
\end{array}$ & $\begin{array}{c}\text { Tota } \\
1\end{array}$ \\
\hline 1 & Manufacturing Company Mining sector, sub-sector of stone mining & 22 \\
\hline 2 & coal was listed on the Indonesia Stock Exchange in 2018-2020 & (2) \\
\hline 3 & Companies that do not issue annual reports to the Stock Exchange & (9) \\
\hline 4 & Indonesia 2018 - 2020 & 11 \\
\hline 5 & Manufacturing companies that suffered losses during 2018-2020 & 33 \\
\hline
\end{tabular}

Data Description

Table 1 Research Sample Selection

The descriptive analysis serves to describe the characteristics of the size of the variables in the study. The results of statistical data from the variables used in this study can be seen in the table below:

\begin{tabular}{|l|c|c|c|c|}
\hline & $\mathrm{Y}$ & $\mathrm{X} 1$ & $\mathrm{X} 2$ & $\mathrm{X} 3$ \\
\hline Mean & 0.127326 & 0.472612 & 1.307 .840 & 1.967 .724 \\
Median & 0.035095 & 0.003755 & 0.747268 & 0.121539 \\
Maximum & 1.514 .565 & 1.541 .152 & 8.077 .281 & 6.027 .375 \\
Minimum & 0.000286 & 0.000178 & 0.376570 & 0.000299 \\
Std. Dev. & 0.299614 & 2.681 .803 & 1.828 .301 & 1.046 .775 \\
Skewness & 3.826 .176 & 5.480 .034 & 2.992 .268 & 5.478 .761 \\
Kurtosis & 1.682 .692 & 3.103 .094 & 1.030 .113 & 3.102 .191 \\
Jarque-Bera & 3.433 .954 & 1.245 .553 & 1.225 .415 & 1.244 .780 \\
Probability & 0.000000 & 0.000000 & 0.000000 & 0.000000 \\
Sum & 4.201 .771 & 1.559 .619 & 4.315 .873 & 6.493 .490 \\
Sum Sq. & & & & \\
Dev. & 2.872 .596 & 2.301 .461 & 1.069 .659 & 3.506 .359 \\
& & & & \\
Observations & 33 & 33 & 33 & 33 \\
\hline
\end{tabular}

3.1 Discussion

Table 2 Descriptive Statistics

\section{Effect of Deferred Tax Expense on Earnings Management}

The results of statistical analysis state that the variable Deferred Tax Expense, the value of the count of 0.118510 with a significance level of $0.3086>0.05$. This shows that the Deferred Tax Expense has no significant effect on earnings management. Based on these results, the results of this study are not by the theory which says that the more profit a company makes, the greater its tax burden. The results of this study do not support the research of Lutfi M

The Influence of Determined Tax Load, Tax Planning, and Profitability in Profit Management in The Company Manufacturing The Mining Sector, The Coal Sub Sector Listed on The Indonesia Stock Exchange Year (Imam Hidayat) 
Baradja, Yuswar Zainul, and Basri Vertari Sasmi.[16] The results of this study support the research of Randi Febrian, Tertiarto Wahyudi, and Ahmad Subek, where the deferred tax burden does not affect earnings management.[17]

\section{The Effect of Tax Planning on Earnings Management}

The statistical analysis results stated that the count value of the Tax Planning variable was $2,028,961$ with a significance level of $0.0417<0.05$. This shows that tax planning has a significant positive effect on earnings management. Based on these results, the results of this study are by the theory which says that the higher the tax planning, the more excellent the opportunity for the company to carry out earnings management. The results of this study do not support the research of Lutfi M BaradjaBudi Setyawan Harnovinsah.[18] The results of this study support the research of Lutfi M Baradja, Yuswar Zainul, and Basri Vertari Sasmi, where Tax Planning has a significant positive effect on earnings management.[19]

\section{The Effect of Profitability on Earnings Management}

The results of statistical analysis state that the Profitability variable count is $8,861,248$ with a significance level of $0.0000<0.05$. This shows that profitability has a significant effect on earnings management. Based on these results, the results of this study are by the theory which says that profitability proxied by the ROA variable has a positive effect on earnings management.[20] Profitability that reflects the company's performance has a significant effect on earnings management, which is caused by the motivation of the management or managers to provide good company performance reports, thus triggering earnings management.[21] By displaying a good profitability value, investors will be interested in investing in the company. Budi Setyawan Harnovinah [22], the results of this study support the research, where profitability has a significant positive effect on earnings management.[23]

\section{Conclusion}

Based on the results of data analysis on the effect of deferred tax expense, tax planning, and profitability on earnings management in Coal Mining sector companies on the Indonesia Stock Exchange in the 2018-2020 period, the following conclusions can be drawn:

1. Deferred Tax Expenses have no significant effect on earnings management in manufacturing companies in the Coal sub-sector Mining sector on the Indonesia Stock Exchange in the 20182020 period.

2. Tax planning significantly affects the profit management of manufacturing companies in the Coal sub-sector Mining sector on the Indonesia Stock Exchange in the 2018-2020 period.

3. Profitability significantly affects the profit management of manufacturing companies in the Coal sub-sector Mining sector on the Indonesia Stock Exchange in the 2018-2020 period.

4. Deferred Tax Burden, Tax Planning, and Profitability simultaneously affect the profit management of manufacturing companies in the Coal sub-sector Mining sector on the Indonesia Stock Exchange in the 2018-2020 period.

\section{References}

[1] M. Amin, J. Susyanti, and M. K. ABS, "PENGARUH PERENCANAAN PAJAK TERHADAP MANAJEMEN LABA PADA PERUSAHAAN MANUFAKTUR YANG TERDAFTAR DI BURSA EFEK INDONESIA PERIODE 2015-2017," J. Ilm. Ris. Manaj., vol. 8, no. 1, 2019.

[2] I. Amsyar, E. Cristhopher, U. Rahardja, N. Lutfiani, and A. Rizky, "Application of Building Workers Services in Facing Industrial Revolution 4.0," Aptisi Trans. Technopreneursh., vol. 3, no. 1, pp. 32-41, 2021.

[3] Y. Croissant and G. Millo, Panel data econometrics with R. John Wiley \& Sons, 2018.

[4] W. Chairunesia, P. R. Sutra, and S. M. Wahyudi, "Pengaruh good corporate governance dan financial distress terhadap manajemen laba pada perusahaan indonesia yang masuk dalam asean corporate governance scorecard," Profita, vol. 11, no. 2, pp. 232-250, 2018.

[5] R. Febrian, T. Wahyudi, and A. Subeki, "Analisis Pengaruh Perencanaan Pajak Dan Beban Pajak Tangguhan Terhadap Manajemen Laba (Studi Kasus Pada Perusahaan Manufaktur Yang Tercatat Di Bursa Efek Indonesia)," AKUNTABILITAS J. Penelit. Dan Pengemb. Akunt., vol. 12, no. 2, pp. 145-160, 2018.

[6] F. F. Bhaktiar and V. S. Hidayat, "Pengaruh Pajak Tangguhan Dan Perencanaan Pajak 
Terhadap Kinerja Perusahaan," J. Akunt., vol. 12, no. 2, pp. 265-276, 2020.

[7] D. Romer, "Macroeconomic theory," Univ. California, Berkeley, 2018.

[8] B. Qi, J. W. Lin, G. Tian, and H. C. X. Lewis, "The impact of top management team characteristics on the choice of earnings management strategies: Evidence from China," Account. Horizons, vol. 32, no. 1, pp. 143-164, 2018.

[9] A. Ratna Komala, "Rps Teori Akuntansi," 2020.

[10] A. K. Badri, J. Heikal, Y. A. Terah, and D. R. Nurjaman, "Decision-Making Techniques using LSTM on Antam Mining Shares before and during the COVID-19 Pandemic in Indonesia," APTISI Trans. Manag., vol. 6, no. 2, pp. 167-180, 2022.

[11] L. Dawati, "Pengaruh Aset Pajak Tangguhan, Beban Pajak Tangguhan dan Perencanaan Pajak Terhadap Manajemen Laba pada Perusahaan Infrastruktur yang Terdaftar di Bursa Efek Indonesia." 2021.

[12] F. Agustin, Q. Aini, A. Khoirunisa, and E. A. Nabila, "Utilization of Blockchain Technology for Management E-Certificate Open Journal System," Aptisi Trans. Manag., vol. 4, no. 2, pp. 133-138, 2020.

[13] R. Fauziah, "Analisis Deferred Tax Asset, Deferred Tax Liabilities, dan Tingkat Hutang Terhadap Manajemen Laba dengan Ukuran Perusahaan sebagai Variabel Moderasi (Studi pada Perusahaan Manufaktur yang Listing di Bursa Efek Indonesia Tahun 20142018)." Universitas Islam Negeri Alauddin Makassar, 2020.

[14] A. Yuliza and R. Fitri, "Pengaruh Beban Pajak Tangguhan dan Perencanaan Pajak Terhadap Praktik Manajemen Laba," AKPEM J. Akunt. Keuang. Dan Akunt. Pemerintah., vol. 2, no. 1, pp. 1-5, 2020.

[15] Q. Aini, S. R. Zuliana, and N. P. L. Santoso, "Management Measurement Scale As A Reference To Determine Interval In A Variable," Aptisi Trans. Manag., vol. 2, no. 1, pp. 45-54, 2018.

[16] R. Deb, "Accounting theory coherence revisited," Manag. labour Stud., vol. 44, no. 1, pp. 36-57, 2019.

[17] D. Christine, J. Wijaya, K. Chandra, M. Pratiwi, M. S. Lubis, and I. A. Nasution, "Pengaruh profitabilitas, leverage, total arus kas dan ukuran perusahaan terhadap financial distress pada perusahaan property dan real estate yang terdapat di bursa efek indonesia tahun 2014-2017," Jesya (Jurnal Ekon. dan Ekon. Syariah), vol. 2, no. 2, pp. 340-350, 2019.

[18] F. Wahidah and S. B. Hermanto, "PENGARUH PERENCANAAN PAJAK DAN MEKANISME CORPORATE GOVERNANCE TERHADAP NILAI PERUSAHAAN," J. IImu dan Ris. Akunt., vol. 7, no. 8, 2018.

[19] Q. Aini, Z. Zaharuddin, and Y. Yuliana, "Compilation of Criteria for Types of Data Collection in Management of Research Methods," Aptisi Trans. Manag., vol. 2, no. 2, pp. 97-103, 2018.

[20] F. Indah Sari, "ANALISIS KEBERHASILAN EQUITY CROWDFUNDING PADA PLATFORM SANTARA." Universitas Pembangunan Nasional Veteran Yogyakarta, 2020.

[21] S. Washington, M. Karlaftis, F. Mannering, and P. Anastasopoulos, Statistical and econometric methods for transportation data analysis. Chapman and Hall/CRC, 2020.

[22] R. Z. Amrullah, "PENGARUH KEBIJAKAN DIVIDEN, KEPUTUSAN INVESTASI, DAN STRUKTUR MODAL TERHADAP NILAI PERUSAHAAN (Studi Kasus Pada Perbankan Nasional yang Terdaftar di BEI Periode 2013-2016)." Universitas Muhammadiyah Semarang, 2018.

[23] J. Q. Dong, P. P. Karhade, A. Rai, and S. X. Xu, "How firms make information technology investment decisions: Toward a behavioral agency theory," J. Manag. Inf. Syst., vol. 38, no. 1, pp. 29-58, 2021.

The Influence of Determined Tax Load, Tax Planning, and Profitability in Profit Management in

The Company Manufacturing The Mining Sector, The Coal Sub Sector Listed on The Indonesia 